\title{
ORESTES, HAMLET E A CONSTITUIÇÁO INFAME DO TRIBUNAL DO JÚRI
}

\author{
ORESTES, HAMLET AND THE INFAMOUS \\ CONSTITUTION OF THE JURY
}

\author{
Augusto Sarmento-Pantoja \\ Universidade Federal do Pará, Faculdade de Ciências da Linguagem, Abaetetuba, PA, Brasil
}

Resumo: O tribunal do júri será revisitado a partir do estudo sobre o teor trágico e a constituição do infame, enquanto ser injustiçado por sua condição subalterna, por meio de releituras das peças de teatro As Eumênides (458 a.C.), de Ésquilo, e Hamlet (1599-1601), de Willian Shakespeare. Realizaremos um confronto entre as personagens nobres dessas peças, Orestes e Hamlet, e a personalidade subalterna do jovem (sem nome) julgado no filme Doze homens e uma sentença (1957), dirigido por Sidney Lumet, apoiados nos estudos de Michel Foucault em A verdade e as formas jurídicas e nos escritos de Giorgio Agamben, em Profanaçóes. Identificamos que a tragédia clássica, por apontar o nascimento do tribunal do júri, promove um julgamento afetado por relaçóes de poder geradoras de medidas diferentes para criminosos diferentes, o que provoca certo conflito em relação à constituição do conceito de infâmia. Já a tragédia barroca tem a necessidade da confissáo do suspeito como prerrogativa para legitimar a vingança, sendo que tal legitimaçáo promove nova visão sobre a condição infame do julgado. Por último, o filme de Sidney Lumet concebe a falência da justiça, que delega o poder condenatório aos que "nada ou pouco sabem" acerca dos códigos jurídicos; por isso, são influenciados por sua idiossincrasia e pela própria encenação performática do tribunal. As três obras acabam por discutir, de formas distintas, várias maneiras de entendermos aspectos infames junto à imagem do tribunal do júri.

Palavras-chave: trágico; infâmia; tribunal do júri; cinema; teatro.

Abstract: The jury was revisited from a study on the tragic content and the creation of the infamous as a person wronged by a subordinate status through reinterpretations of the plays The Eumenides (458 BC) by Aeschylus, and Hamlet (1599-1601) by William Shakespeare. We held a confrontation between the noble characters of these plays, Orestes and Hamlet, and the subordinate personality of the (unnamed) young man tried in the movie 12 Angry Men (1957), directed by Sidney Lumet, supported in studies by Michel Foucault in Truth and juridical forms and writings by Giorgio Agamben in Profanations. We identified that classic tragedy, for pointing out the birth of the jury, promotes a trial affected by power relations that institute different measures for different offenders, which causes some conflict regarding the constitution of the concept of infamy. On the other hand, baroque tragedy has the need of the suspect's confession as a prerogative to legitimize revenge, and such legitimacy promotes a new view on the infamous condition of the tried man. Finally, the movie by Sidney Lumet conceives the failure of justice, which delegates the convicting power to those who "know little or nothing" about the legal codes. Therefore, they are influenced by their idiosyncrasy and their own performative enactment of the court. The three works end up discussing, in different ways, 
many forms to understand infamous aspects with the image of the jury.

Keywords: tragic; infamy; jury; cinema; theater.

Entendamo-nos bem. Não ponho eu mira na posse do que o mundo alcunha gozos. O que preciso e quero é atordoar-me. Quero a embriaguez de incomportáveis dores, a volúpia do ódio, o arroubamento das suas afliçôes. Estou curado das sedes do saber; de ora em diante às dores todas escancaro est'alma. As sensaçóes da espécie humana em peso, quero-as eu dentro de mim; seus bens, seus males mais atrozes, mais íntimos, se entranhem aqui onde à vontade a mente minha os abrace, os tateie; assim me torno eu próprio a humanidade; e se ela ao cabo perdida for, me perderei com ela. (Goethe ${ }^{1}$ ).

Sentir, mirar, gozar. Essa multiplicidade está imersa na leitura do teor trágico disposta no Fausto de Goethe, pois leva o homem a questionar a sua própria natureza humana em busca de um eu interior que possa congregar dentro de si os antagonismos. Esses, por sua vez, se encontram de certa forma também presentes em Hamlet $^{2}$, de Shakespeare, ao imortalizar seu monólogo sobre a impossibilidade do conhecimento interior.

Ser ou não ser... Eis a questão. Que é mais nobre para a alma: suportar os dardos e arremessos do fado sempre adverso, ou armar-se contra um mar de desventuras e dar-lhes fim tentando resistir-lhes? Morrer... dormir... mais nada... Imaginar que um sono põe remate aos sofrimentos do coração e aos golpes infinitos que constituem a natural herança da carne é soluçấo para almejar-se. Morrer.., dormir... dormir... Talvez sonhar... É aí que bate o ponto. $\mathrm{O}$ não sabermos que sonhos poderá trazer o sono da morte, quando ao fim desenrolarmos toda a meada mortal, nos póe suspensos. É essa ideia que torna verdadeira calamidade a vida assim tăo longa! Pois quem suportaria o escárnio e os golpes do mundo, as injustiças dos mais fortes, os maus-tratos dos tolos, a agonia do amor náo retribuído, as leis amorosas, a implicância dos chefes e o desprezo da inépcia contra o mérito paciente. Se estivesse em suas máos obter sossego com um punhal? (SHAKESPEARE, 2000, p. 64-65).

${ }^{1}$ GOETHE, Johann Wolfgang. Fausto: Quadro V, Cena I. Traduçẫo Antônio Feliciano de Castilho. Clássicos Jackson. v. 15. Aveiro-Portugal: Universidade de Aveiro; W. M. Jackson Editores, 1956. p. 135. Arquivo disponível em meio virtual em:< http://www.superdownloads. com.br/download/159/fausto-goethe/>.

${ }^{2}$ Todas as notas a seguir da obra de Willian Shakespeare, Hamlet: o príncipe da Dinamarca, Trad. F. Carlos de Almeida Cunha Medeiros e Oscar Mendes. Sáo Paulo: Virtualbooks; M\&M, 2000. Disponível em meio virtual em: <http://virtualbooks.terra.com.br/freebook/ shakespeare/hamlet.htm>. 
Essa seria a natureza do homem moderno em relação à eterna dúvida entre a apatia e a resistência, uma espécie de simplificação do trágico moderno. Mas qual seria então a funçáo da vida em meio à calamidade de sua longitude? Sem dúvida, com Fausto e Hamlet compreendemos que o trágico moderno perfilha diferenças fundamentais para com sua mãe helênica, mas também exprime algumas aproximaçôes. As diferenças compóem um quadro interessantíssimo quando nos detemos em pensar a tragédia enquanto forma estética, isso porque a introspecçáo nela presente leva o homem a buscar, no seu interior, as respostas para os conflitos expressos ao seu redor. Por conseguinte, há várias possibilidades para a formalização do desejo de autoconhecimento. Em Goethe, para que haja a concretização do gozo, será necessário estar imerso no atordoamento, na embriaguez, na volúpia, no ódio. De certo modo, Hamlet colabora nessa proposiçáa de Goethe ao considerar necessário um estado onírico para que a busca seja possível, pois seria "mais nobre para a alma suportar os dardos e arremessos do fado sempre adverso, ou amar-se contra um mar de desventuras e dar-lhes fim tentando resistir?" (SHAKESPEARE, 2000, p. 64). Daí a necessidade dos estados oníricos para curar tais sofrimentos, sejam eles por meio da morte, golpe final; do sono, estado de latência; do sonho, a cura ilusória.

A tentativa de compreender o porquê de si e/ou o porquê do outro marca a tragédia tanto nas instâncias míticas do Olimpo quanto naquelas em que os heróis estáo mais preocupados em construir as defesas de seus próprios crimes. Se, por um lado, as tragédias clássicas são marcadas pela insensata disputa e pela necessidade de defender e/ou condenar os mortais, de outro lado, a tragédia moderna, para Nietzsche, apresenta a constituiçáo de um tribunal para o deleite moral do espectador, que deve sentir prazer em assistir a puniçẫo imposta aos heróis ou a seus acólitos.

O castigo arbitrado desdobra-se por meio de um ato individual de sua vontade, gerando, por conseguinte, a formação de um estado interior de culpa, a qual, por sua vez, será compelida à punição, que tarda, mas não falha para esses criminosos. Mas de quais crimes e de quais criminosos falamos? Fiodor Dostoiévski (1998), em Crime e Castigo, reflete sobre a natureza do crime, considerando que existem dois lados de uma mesma moeda, um em que náo se pode produzir o crime; outro, em que os crimes são toleráveis. Vejamos o diálogo de Raskólhnikov, Razumíkhin e Porfíri.

- Como? Que vem a ser isso? O direito ao crime?! Mas não será por culpa do ambiente deletério! - perguntou Razumíkhin um pouco assustado. Não, não; não é nada disso - respondeu-lhe Porfíri. - O que está em que no seu artigo o senhor divide os homens em ordinários e extraordinários. Os 
homens vulgares deviam viver na obediência e não têm direito a infringir as leis, pelo próprio fato de serem vulgares. Mas os extraordinários têm direito a cometer toda a espécie de crimes e a infringir as leis de todas as maneiras, pelo próprio fato de serem extraordinários. Se não estou enganado, pareceme que era isso o que o senhor dizia (DOSTOIÉVSKI, 1998, p. 281).

Dois pesos, duas medidas! Temos aqui uma prática cada vez mais cotidiana nos ditames da lei, promotora de inúmeras críticas à justiça, fazendo com que se deflagrem, no âmbito literário, debates continuados acerca da natureza transgressora e criminosa da humanidade. A justiça busca reagir contra essa problemática quando concebe a constituição do tribunal do júri, que delega ao cidadão comum o arbítrio da condenação. A constituição de um júri daria outra roupagem para o julgamento pelo fato de garantir a possibilidade de outros olhares, outros ouvidos, outras impressóes no difícil ofício de julgar. Mas até que ponto esse júri está comprometido com tal incumbência? De qual júri falamos? De quais comprometimentos e para com quem?

Considerando os aspectos até aqui expostos tomamos a partir de então o comprometimento do júri como um constituinte importante no debate sobre as representaçóes do crime no campo artístico e ético. Com base nisso, analisaremos o filme Doze homens e uma sentença e também as tragédias Eumênides e Hamlet.

\section{II}

A diferenciação entre homens perpassa por suas diferentes naturezas, pois sua posição social será outorgada como paradigma, presente desde as tragédias clássicas, especialmente quando é colocada em cena a tarefa do tribunal. Para tanto, trazemos até aqui o caso de Orestes, na constituição do tribunal, em Eumênides, e o do filme Doze homens e uma sentença. Os réus são diferentes, um representa o homem extraordinário (Orestes), e o outro, um homem ordinário (sem nome). Orestes é um criminoso confesso, mas pertence à cúpula do poder. Já o réu do filme é um submerso, pobre, morador de uma favela. Orestes, de certo modo, é beneficiado ao infligir as leis naturais, como o matricídio, pelo fato de seu crime ser assegurado por Apolo e pela própria cultura helênica. A narrativa sofre uma virada quando Orestes passou a ser defendido pelos que deveriam julgá-lo (As Parcas), o que vai afastá-lo do rótulo de infame. 
Veio de Zeus, segundo tu mesmo disseste, a determinação oracular a Orestes para vingar $\mathrm{o}$ assassinato de seu pai sem nada impor em relação à sua mãe?

(ÉSQUILO, 2010, p 176)

Orestes foi autorizado pelo Olimpo e, nesse sentido, fica demarcado que as medidas da lei serão aplicadas sobre os ditames da sensatez e da ponderação, ou seja, sem a condenação imediata indicada aos homens vulgares, infames ou ordinários. Ao pensarmos em Crime e Castigo, em Eumênides, e em Doze homens e uma sentença, observamos um modelo de tribunal que está a subtrair-se naquele em que o tratamento diferenciado aos homens se fundamenta na possibilidade de interpretar a lei de acordo com certas conveniências e padróes, o que se dá por parte de quem detém o poder do julgamento. Isso, em muitas situaçóes, acaba sendo utilizado como artifício para burlar essa lei, contribuindo para o aprofundamento dos modelos sociais apoiados na manutenção dos abismos classistas. Utilizando como argumento a existência de diversas formas de verdade nas muitas maneiras de se ler a história, Foucault (2002) destaca em A verdade e as formas jurídicas:

[...] a maneira pela qual, entre os homens, se arbitram os danos e as responsabilidades, o modo pelo qual, na história do Ocidente, se concebe e se definiu a maneira como os homens podiam ser julgados em função dos erros que haviam cometido, a maneira como se impôs a determinados indivíduos a reparaçẫo de algumas de suas açôes e a punição de outras, todas essas regras ou, se quiserem, todas essas práticas regulares, é claro, mas também modificadas sem cessar através da história - me parecem uma das formas pelas quais nossa sociedade definiu tipos de subjetividades, formas de saber e, por conseguinte, relaçóes entre o homem e a verdade (FOUCAULT, 2002, p. 11).

A verdade e a história que, nas práticas jurídicas, a priori, são inquestionáveis e irrefutáveis, precisarão ser revistas e ressignificadas com a constituição do júri, pois não será possível pensar no julgamento sem essas representaçóes e sem multiplicidades de interpretaçôes e intérpretes dos autos do crime.

Ésquilo, em Eumênides, propôe a primeira cena de um julgamento; nesse caso, amparado pelo poder de persuasão dos deuses, Palas Atena e Apolo. A narrativa discute o poder de convencimento da deusa Palas Atena, posta como a juíza do caso. As Parcas, nessa tragédia, serão as representantes da acusaçáo contra Orestes, assassino de sua mãe (Clitemnestra) por honra 
a seu pai (Agamêmnon) - este, anteriormente, responsável pelo sacrifício de sua filha (Ifigênia) em oferenda aos deuses, com intuito de garantir proteção na empreitada sobre Tróia.

Durante a narrativa, o crime de Orestes não será negado, nem escondido, pelo contrário, será justificado e defendido pelos deuses por se tratar de um crime com uma justificativa tenaz, a reparação por causa do assassinato do pai de maneira vil. Ao mesmo tempo, a morte de Clitemnestra é desprezada. Vários motivos podem colaborar com tal abordagem para com a mulher, entre elas, destacamos os laços consanguíneos. A narrativa de Ésquilo considera que a mãe ou a mulher possui o papel de geradora e não de genitora; dessa forma, a morte da mãe, ou de qualquer outra mulher, não significaria um crime de sangue, porque:

\author{
Aquele que se costuma chamar de filho \\ não é gerado pela mãe - ela somente \\ é a nutriz do germe nela semeado -; \\ de fato, o criador é o homem que a fecunda;
}

(ÉSQUILO, 2010, p. 177-178)

Em sua arguição em defesa de Orestes, Apolo pormenoriza o crime de Orestes e apoia sua vingança e a condenação de Clitemnestra pela morte de Agamêmnon, pois, nesse caso, a mulher seria aquele ser ordinário, que não tem direito de descumprir a lei, mesmo que o crime praticado por Clitemnestra fosse para vingar a morte de sua filha Ifigênia, sacrificada por Agamêmnon. Vejamos a defesa de Apolo:

\footnotetext{
Sim, veio, pois é totalmente diferente a morte de um herói ilustre, respeitado por ser o detentor do cetro instituído graças à vontade divina; mais ainda: ele foi atingido por uma mulher não com um arco excepcional de longo alcance, desses usados pelas bravas amazonas, e sim da forma insidiosa que ouvireis, tu, Palas, e vós, os juízes impolutos, sentados nesta corte para decidir com vossos votos a questão em julgamento. O marido voltava de uma guerra longa, depois de vencer quase todas as batalhas; sua mulher o recebeu com falso amor, e levou-o a banhar-se; quando ele saía da banheira sinistra, ela o envolveu num longo manto e num instante o abateu, preso naquele pano cheio de bordados
} 
como se fosse uma armadilha sem saída.

Foi este o fim ignóbil de um herói sem par,

(ÉSQUILO, 2010, p. 176)

A tragédia clássica em questão diferencia homem e mulher diante de seu crime. Entretanto, questionamo-nos se realmente seria possível vêlos como seres infames. Certamente não, se pensarmos nos parâmetros da época; mas, atualizando seus crimes, facilmente teríamos como chamá-los assim. Obviamente, tomando as devidas reservas quanto ao tempo, ao espaço e à função estética desses crimes. Apesar de diferentes, conseguem produzir o incômodo necessário ao questionamento do tribunal como uma forma abjeta de justiça, justamente por ser afetado pela ideia de diferenciação entre os homens, o que precede ao próprio julgamento.

Tais diferenciaçóes existentes tomam os argumento de Apolo no anseio de diferenciá-los e defender Orestes. Nesse sentido, a interpretação dos crimes de filho e mãe segue a lógica do valor e da funçáo das personagens no universo social grego. A morte de seu pai, de forma pífia, não seria aceita por se tratar de um herói de alto quilate; por esse motivo, isso seria inconcebível a um herói: "depois de vencer quase todas as batalhas; sua mulher o recebeu com falso amor, e levou-o a banhar-se; quando ele saía da banheira sinistra, ela o envolveu num longo manto e num instante o abateu" (ÉSQUILO, 2010, p. 176). Contrastando com a condição feminina e materna de Clitemnestra, para Apolo eles não possuem a mesma função social, tanto que:

[...] ela, como uma estranha, apenas salvaguarda o nascituro quando os deuses não $o$ atingem.

Oferecer-te-ei uma prova cabal de que alguém pode ser pai sem haver mãe. Eis uma testemunha aqui, perto de nós - Palas, filha do soberano Zeus olímpico -, que náo cresceu nas trevas do ventre materno; alguma deusa poderia por si mesma ter produzido uma criança semelhante? De minha parte, Palas, sábio como sou, darei glória a teu povo e à tua cidade; quanto a Orestes, que chegou até aqui como teu suplicante, fui seu condutor até a frente de teu templo e tua imagem. (ÉSQUILO, 2010, p. 178) 
A defesa de Apolo náo se limita a questionar o valor da mulher e da máe para a manutenção da sociedade grega; ele apela para a responsabilidade dos deuses para com os homens, apontando que tanto Atena possui motivos suficientes para defender Orestes quanto Apolo, isso porque o jovem assassino é um súdito exemplar para com os deuses, em especial para com a deusa da justiça. Desse modo, o julgamento feito por Atena, enquanto juíza desse tribunal, mostra-se tendencioso, uma vez que a própria juíza também será defensora do réu. Para firmar a garantia de absolviçáo de Orestes, restalhe convencer as Parcas, principais perseguidoras do réu, da inocência do jovem. Vejamos como isso se dá:

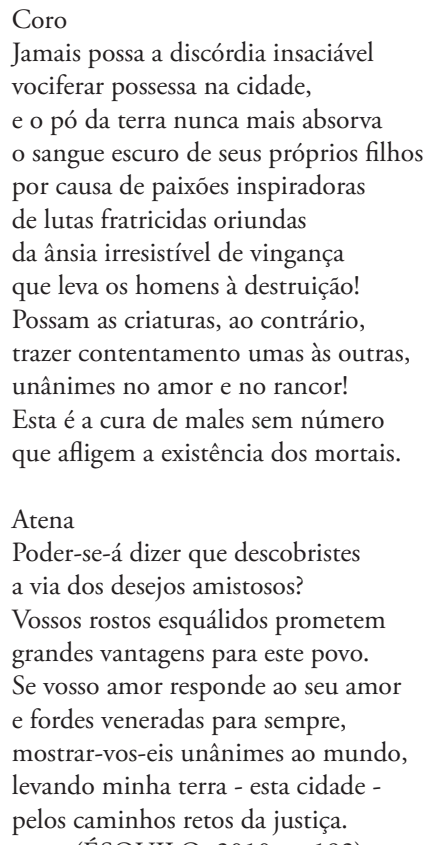

A estratégia da deusa da justiça compreende a extrema valorizaçáo da importância das Parcas na governança sobre os homens, reestruturando, assim, sua posição no discurso. De acusadoras e perseguidoras de Orestes, passam a aceitar o crime diante do apaziguamento da violência. Nesse sentido, seria fundamental o arrependimento dos homens na busca de que eles possam "trazer contentamento umas às outras, unânimes no amor e no rancor! Esta é a cura de males sem número que afligem a existência dos 
mortais" (ÉSQUILO, 2010, p. 192). O convencimento será cultivado por Atena junto às Parcas, por meio da difusão de sua vaidade e da promessa de homenagem em público. As Parcas são seduzidas pela vaidade e, em nome dela, mudam de atitude; cooptadas por Atena, deixam os caminhos da condenação e constroem um discurso de júbilo:

\author{
O povo preferido por Atena \\ acaba de ganhar a paz aqui \\ para a felicidade de seus lares, \\ e assim vemos selar-se a uniáo \\ entre as Parcas e Zeus onividente! \\ (ÉSQUILO, 2010, p. 194)
}

\begin{abstract}
III
Saindo da esfera das tragédias clássicas propriamente ditas, temos em Hamlet outro caso de constituição do júri. Dessa vez, o acusador busca o convencimento do criminoso para que confesse seu delito em público, pois, somente desse modo, poderá ter legitimidade para cumprir sua promessa de vingança. Diferente do que acontece com Orestes, Hamlet não é o criminoso, mas deseja sê-lo. Tornar-se criminoso possui, assim como acontece com Orestes, a necessidade de justificativa; neste caso, a justificativa se faz com a confissão dos matadores de seu pai. A confissão de um crime em Hamlet garante o direito de vingança sem culpa, sem piedade. Mas acusar e culpar obriga o protagonista a recorrer aos caminhos jurídicos. É nesse sentido que dizemos que Shakespeare recorre à encenação do crime, usando atores que recuperam a versão desconhecida do crime contra o pai de Hamlet:
\end{abstract}

Hoje há espetáculo ante o rei, com uma cena igual às circunstâncias da morte de meu pai, como eu te disse. Quando chegar essa passagem, peço-te que com todas as forças de tua alma observes a meu tio. Se seu crime não se manifestar ante um discurso, é que era alma penada o que nós vimos e mais negras as minhas fantasias que a forja de Vulcano. Observa-o bem. Hei de os olhos cravar-lhe no semblante; juntaremos depois nossos juízos para julgarlhe o aspecto (SHAKESPEARE, 2000, p. 71).

Hamlet deixa claro que busca produzir uma espécie de efeito catártico contra seu tio, que, diante da recuperação da cena primeva do assassinato, ficaria tomado de culpa ao assistir, diante si, o que esconde como verdade. A elucidação do crime e das circunstâncias em que ele se deu será possível graças à conversa de Hamlet com o fantasma de seu pai, revelando que seu 
algoz ocupa o trono da Dinamarca. Chamamos aqui atenção para o fato de que as duas narrativas utilizam uma estratégia curiosa para recuperar o testemunho catastrófico das narrativas de assassinato, a saber, a incorporação de uma personagem fantasmagórica, vinda do além. O fantasma do Rei em Hamlet e $\mathrm{O}$ fantasma de Clitemnestra em Eumênides retornam de um outro mundo, imbuídos da missão de "acordar" os representantes da justiça contra seus assassinos, na primeira narrativa Hamlet; na segunda, o Coro das Fúrias, como elucida o Fantasma de Clitemnestra:

\author{
Dormis profundamente! Qual a serventia \\ de sonolentas como vós? Por vossa causa \\ sou vilipendiada no mundo dos mortos, \\ que não cessam de me humilhar qualificando-me \\ injuriosamente de assassina, lá, \\ vagando envergonhada em meio a tantas sombras! \\ $[\ldots]$ \\ Continuais dormindo e não vos comoveis \\ com meu enorme sofrimento!O criminoso, \\ o matricida Orestes, desapareceu! \\ (ÉSQUILO, 2010, p. 151-152)
}

E do fantasma do Rei:

Sou a alma de teu pai, por algum tempo condenada a vagar durante a noite, e de dia a jejuar na chama ardente, até que as culpas todas praticadas em meus dias mortais sejam nas chamas, ao fim, purificadas. [...] Escuta, Hamlet! Se algum dia amaste teu carinhoso pai...

[...]

Vinga o seu assassínio estranho e torpe.

$[\ldots]$

Mas escuta, nobre mancebo! A cobra que peçonha lançou na vida de teu pai, agora cinge a coroa dele.

(SHAKESPEARE, 2000, p. 35-36)

Verifica-se nas duas falas que os fantasmas retornam para revirar os brios de seus defensores para que possam realizar a vingança a contento. No entanto, só o fantasma do Rei terá sucesso em sua empreitada. Clitemnestra, por ser mulher, não terá sua vingança atendida. Claro que esse não será o único motivo para que a vingança náo ocorra, pois, nesse caso, temos uma vingança sobre vingança, em um contexto em que irá predominar o poder patriarcal sobre o maternal.

Outro ponto em comum expresso nas referidas narrativas será o teor testemunhal presente na voz subterrânea dos fantasmas. O testemunho do 
assassinato, contado pela voz superstes da vítima, não terá outra maneira de revelar os detalhes de sua morte e apresentar uma nova versáo dos fatos, contrapondo aos discursos oficiais, a não ser essa. Sabemos, entretanto, que o narrador superstes, para Benveniste (1995), representa não só o evento catastrófico por ele vivido, mas também a possibilidade de ser o testemunho de si mesmo, reelaborando sua própria experiência trágica. Nas tragédias aqui analisadas, nem um dos dois são sobreviventes, mas sim seus espectros, porém transfigurados, como se fossem testemunhas de suas próprias mortes, já que saem do limbo para promover o questionamento da verdade e da história.

Manter-se no fato catastrófico, ser parte de um passado que permanece presente é o que os condena à condição fantasmagórica. A metáfora do fantasma, por sua vez, refere-se àquele que está no entremezo, no não lugar, vivo e morto, presente e ausente. Todas essas adjetivaçóes podem ser perfeitamente entendidas nos diversos narradores superstes, mesmo aqueles que estão vivos e sobreviveram. Em Eumênides, a narradora de sua tragédia possui em si o peso de seu próprio crime, diferentemente do fantasma em Hamlet, que, seguindo a argumentaçáo de Dostoievski, representa o ser extraordinário, que será descrito por Shakespeare, por meio de Hamlet, como "um rei tão bom, que, confrontado com este, era Apolo ante um sátiro... Tẫo terno para a esposa, que ao próprio vento obstava de bater-lhe no rosto com violência" (SHAKESPEARE, 2000, p. 24). As qualidades de seu pai contrastam com a sua dor e com a necessidade do luto, especialmente ao questionar o contraste entre o seu sofrer e o de sua mãe. Seu sofrer era tão intenso a ponto de pensar em sua própria morte:

HAMLET: Oh, se esta carne sólida, tẫo sólida, se desfizesse, fundindo-se em orvalho! Ou se ao menos o Eterno não houvesse condenado o suicídio! Ó Deus! Ó Deus! Como se me afiguram fastidiosas, fúteis e vấs as coisas deste mundo! Que horror! Jardim inculto em que só medram ervas daninhas, cheio só das coisas mais rudes e grosseiras. Chegar a isso! Morto há dois meses! Não, nem tanto... Dois? (SHAKESPEARE, 2000, p. 24).

Ao contrário, sua mãe infligira os preceitos do luto ao se casar com seu tio, em táo pouco tempo após da morte de seu pai. Uma espécie de prenúncio de que havia algo de errado com aquela relação:

E um mês depois... Paremos. Fragilidade, nome de mulher... Só um mês, sem ter gasto ainda os sapatos com que o corpo seguiu do meu bom pai, qual Níobe, só lágrimas. Sim, ela - Ó céu! Um animal que é destruído da faculdade da palavra, certo choraria mais tempo! - desposada! pelo irmão de 
meu pai, mas que tem tanto dele tal como eu de Hércules. Num mês, antes que o sal das lágrimas tão falsas secassem de seus olhos tumefeitos estar ela casada! Oh! pressa iníqua de subir para o tálamo incestuoso! Não pode acabar bem... Mas despedaça-te, coração; é mister ficar calado (SHAKESPEARE, 2000 , p. 24).

A incerteza ainda se faz presente, pois Hamlet, nesse momento da narrativa, ainda náo possui os dados que possam nutrir sua desconfiança; por isso, tem necessidade de promover a confissáo do rei, por meio da culpa proporcionada pela encenação dos atores. Consternado pela cena, o rei, sozinho no quarto, diz:

Está podre o meu crime; o céu já o sente. A maldição primeira pôs-lhe o estigma: fratricida. Rezar, não me é possível, muito embora o pendor siga à vontade; a culpa imana vence o belo intento. Tal como alguém que empreende dois negócios ao mesmo tempo, mostro-me indeciso sobre qual inicie, acontecendo vir ambos a perder. Se esta maldita mão de sangue fraterno se cobrisse, não haveria chuva suficiente no céu, para deixá-la como a neve? Para que serve a Graça, se não serve para enfrentar o rosto do pecado? $\mathrm{E}$ a oração, não contém dupla virtude, de prevenir a queda e obter completo perdão para os que caem? Alço os olhos. Meu crime já passou; mas, que modelo de oração servirá para o meu caso? Perdoai-me o crime monstruoso e horrendo? (SHAKESPEARE, 2000, p. 83).

A cena dentro da cena, estratégia metateatral elaborada por Hamlet para pressionar seu tio a se autodelatar, surtiu o efeito desejado. Mas nem tudo ocorre como planejado pelo jovem, já que a confissão não é realizada em público, pois o rei se afugenta em um dos quartos do castelo e, no momento que se encontra só, declara sua culpa. Contudo, o fato de a confissão ter sido realizada passa a ser suficiente para o desencadeamento das açôes vingativas de Hamlet em favor de seu pai assassinado. A tragédia finaliza com a morte de todo o trono dinamarquês por meio de uma espécie de envenenamento coletivo, preparado pelo Rei contra Hamlet, mas que acaba atingindo a todos. Crime, acidentes, peripécias! Todos tiveram seu fim exemplar, infame, mortal.

\section{IV}

A sala do júri é um espaço que pertence à modernidade. E quando pensamos em um tribunal moderno, devemos lembrar que a cena do julgamento aparece apenas como introito e dá lugar a um debate que fica às escuras quando se trata da sala do júri. Além disso, quase nada sabemos 
sobre o que acontece nesses espaços de julgamento, pois o que vem a público são apenas os resultados desses debates, ou seja, a culpa ou a inocência, que, ao se transformarem em sentenças, se tornam, quase sempre, inapeláveis e irreparáveis. No caso do filme Doze homens e uma sentença, encontra-se em debate a pena capital. Desse modo, a condenação do suposto homicida fatalmente o levará à cadeira elétrica. Essa película questiona a natureza das provas, das sentenças, das evidências. Nesse sentido, póe-se em dúvida toda a cena do tribunal, pois os fatos podem ser criados e recriados; por isso, não podemos deixar de lado a análise de como são apresentados e de quem apresenta os fatos, ao mesmo tempo em que ele se desloca contra quem tais fatos se apresentam.

A isenção da justiça, do juiz, dos advogados e principalmente do corpo de jurados ganha evidência, já que a perspectiva cinematográfica proposta por Sidney Lumet gera a quebra das fronteiras entre o tribunal e a sala do júri, cujo interior será revelado ao expectador. A narrativa de Doze homens e uma sentença fundamenta-se assim no questionamento das evidências. Seu discurso pauta-se em elucidar o quanto o tribunal do júri se deixa influenciar muito mais pelos estereótipos sociais do que pela análise dos fatos, das provas, das evidências. Desse modo, o desnudamento das evidências questiona as certezas e determina faces impensadas até então em relação à racionalidade e à precisão das instituiçóes jurídicas. Mas a instituição jurídica acaba por ser salva, pela insistência de um dos jurados, que, ao tentar romper com os modelos ali instalados, faz com que a fabulação passe a apontar para eficácia do júri, mesmo diante da inércia do tribunal, cuja complexa constituição é demarcada por algumas cenas que evidenciam a vulnerabilidade a que está sujeito. Destacamos duas dessas cenas que avaliamos serem representativas dessa vulnerabilidade: uma em que ocorre o confronto entre diferentes perspectivas, em ambas predominando uma consequência negativa para o bom andamento do ato de julgar, e outra em que observamos a indiferença dos julgadores.

Na primeira cena, os membros do júri, em número de doze homens, estâo distribuídos entre jurados inexperientes e experientes, gerando uma dicotomia: de um lado, é possível perceber a novidade entranhada na primeira experiência. De outra parte, temos a desilusão pela função de jurado. Essa dicotomia pode ser apreendida no diálogo entre o jurado 2, interpretado por John Fiedler, e o jurado 3, interpretado por Lee J. Cobb:

- O que achou?

- Não sei. Foi interessante?

- É mesmo? Eu quase dormi. 
- É que eu nunca participei de um júri antes.

- É? Eu já participei de muitos. Irrita-me como os advogados são prolixos. Mesmo em casos tão óbvios. Viu como falam sem parar?

- Acho que estão em seu dever.

- É estấo. O sistema é assim. Mas, se quer saber, derrubava aqueles sabichōes antes de termos mais problemas. Pouparia tempo e dinheiro.

(LUMET, 1957, 0:06'09”- 0:06'39").

Há uma segunda cena, na qual notamos que, para muitos dos jurados, a atividade será ainda enfadonha e associada a uma obrigação burocrática que os convocados devem cumprir sem delongas, como aponta o jurado 7 , interpretado por Jack Warden: "É, vamos votar. Quem sabe possamos ir logo embora” (LUMET, 1957, 0:10'47” - 0:10'51”). Certamente, eles desejam retornar às suas vidas, mesmo que essas vidas, daquele ponto em diante, pudessem ser modificadas por cada experiência vivida naquela sala do júri, uma vez que deixam suas vidas comuns e passam a ser responsáveis pela vida e pela morte do réu; por isso, tornam-se uma espécie de "advogados" de defesa e de acusação, como alerta o juiz, interpretado por Rudy Bond:

\begin{abstract}
Ouviram um longo e complexo caso de homicídio em $1^{\circ}$ grau. Um homicídio premeditado é a mais grave acusação em nossos tribunais. Ouviram os testemunhos. A lei lhes foi lida para ser aplicada ao caso. Agora é dever de vocês tentar separar os fatos, da versão. Um homem está morto. A vida de outro está em jogo. Se houver dúvida razoável sobre a culpa do acusado... dúvida razoável, devem entregar-me o veredicto de inocente. Se, entretanto, não houver... devem, em sã consciência declarar o acusado culpado. O que quer que decidam, o veredicto deve ser unânime. No caso de julgarem o acusado culpado... o tribunal não considerará a hipótese de perdão. A sentença de morte é compulsória neste caso. Estão frente a grande responsabilidade (LUMET, 1957, 0:01'20" - 0:02'27”).
\end{abstract}

A responsabilidade de julgar será destinada a outrem, que, sem formação jurídica, busca entender os fatos e tirar conclusóes baseadas em suas normas, em seus desejos e em seus preconceitos, como ocorre com o Jurado 10, interpretado por Ed Begley, ao afirmar, no início do filme, sua posição: "Ouvimos os fatos, não foi? Não quer que acreditemos no rapaz, sabendo o que ele é. Convivi com eles a vida toda. Náo se pode acreditar em nada que dizem. Sabem disso. Já nascem mentirosos" (LUMET, 1957, $0: 1426$ " - 0:14'39"). Esse posicionamento determinista cobrirá parte do debate até o final do julgamento dos jurados, ao ponto de esse mesmo jurado, mesmo quando a maioria já tinha mudado de opiniáo e passara a pôr em dúvida a culpa do jovem réu, posicionar-se novamente com os mesmos argumentos do início do filme: 
Viram o rapaz tanto quanto eu. Náo me digam que acreditam naquela história da perda da faca e da ida ao cinema. Sabem como essa gente mente! Já é uma coisa nata. Que diabos! Não precisa dizer. Eles nấo sabem o que é verdade e não precisam de motivo para matar alguém. Não, senhor! Ficam bêbados. Bebem como gambá, todos eles! Sabem disso. E pronto! Já há alguém caído na sarjeta. Ninguém os está culpando. É o modo como são. Entende? Violentos! Aonde vai? A vida humana não significa o mesmo para eles. Eles só vivem enchendo a cara e brigando! E se alguém morrer, morreu! Não ligam (LUMET, 1957, 1:17'55” - 1:18’37”).

O acusado será caracterizado como um animal, bêbado, para quem a vida humana não importa e, por isso, deve ser condenado. Profundo preconceito, náo mais partilhado pela maioria dos jurados, porém representativo da conotação mais costumeira dos tribunais do júri, que ali está sendo questionada. Nessa situaçáo específica, caso o jurado 8, Davis, interpretado por Henry Fonda, náo estivesse estarrecido com o pouco caso da justiça para realizar um julgamento realmente isento dos preconceitos, especialmente os de classe, teríamos outro encaminhamento na condução desse julgamento. Por essa abordagem, a ineficácia proposital da justiça fez com que houvesse a percepçáo, para o corpo de jurados, de que as evidências garantiam a culpa do jovem acusado, antecipadamente instaurada, inclusive pelo advogado indicado para defendê-lo, como nos informa Davis:

Que não queria o caso nem ser escolhido. È o tipo de caso que não traz louros. Nem muita chance de vencer. Não é uma situação promissora para um jovem. Teria que acreditar nele para se esforçar. E como disse, não acredita (LUMET, 1957, 0:47’47”- 0:48'03”).

Cabe à acusação o ônus da prova e cabe à defesa construir os argumentos necessários ao convencimento da inocência do réu. Mas como fazer se as provas náo são suficientes? Diante desse questionamento, apresentado pela narrativa de Doze homens e uma sentença, uma problematizaçáo, que implica o testemunho, se eleva. De fato, é preciso colocar em cena o testemunho, pois somente com o relato testemunhal será possível reconstruir a cena criminosa diante do juiz e do corpo de jurados. A verdade dos fatos agora fica a cargo daqueles que devem jurar dizer a verdade. Mas de qual verdade estamos tratando? Essas são algumas perguntas que defesa e acusação apontam no tribunal para qualificar ou desqualificar o testemunho. $\mathrm{O}$ que fazer quando o próprio responsável por sua defesa não acredita na inocência do réu? Seria possível, dessa maneira, defender alguém?

Sem nenhum tipo de dificuldade, o que restou para o caso foi a 
imposição de suas idiossincrasias, por parte da acusação, relativizando o crime tal como apontou Dostoievski (1998) em Crime e Castigo, ao separar os homens em duas categorias: ordinários e extraordinários, tal qual já fizera séculos antes Aristóteles (2000), em sua Poética, ao indicar a existência de duas espécies de homens, representantes de duas espécies de formas poéticas, por isso, "uma se propóe imitar os homens, representando-os piores; a outra os torna melhores do que são na realidade" (ARISTÓTELES, 2000, p. 03). Medidas as devidas proporçóes e diferenças de tempo e de produçãa, Aristóteles e Dostoievski caracterizam a instável realidade do direito na análise dos julgados, pois previamente deve ser considerada a "natureza" ordinária ou extraordinária neles implicados.

Quando a natureza ordinária é evidenciada, associamo-la como própria dos homens infames, como caracteriza Michel Foucault no ensaio $A$ vidas dos homens infames, ao considerar que são "infames, por causa das abomináveis recordaçôes que deixaram, das malfeitorias que se lhes atribuem, do respeitoso horror que inspiraram" (FOUCAULT, 1992, p. 103-104). Muitas vezes, os homens infames sáo o jovem morador da favela, migrantes que falam mal o idioma local e, por isso, já são condenados. Desse modo, não será à toa que o jovem de 18 anos, réu em Doze homens e uma sentença, será julgado como homem vulgar que não têm direito algum, inclusive o de infringir as leis, como entende um dos jurados mais entusiastas de tal tese determinista, o jurado 10, interpretado por Ed Begley. Para ele, "o rapaz é mentiroso! Sei tudo sobre eles. Ouçam-me! Eles não prestam! Não tem um que preste!" (LUMET, 1957, 1:18'57” - 1:19'05”).

O pré-julgamento traz consigo o confronto direto com as instâncias jurídicas pelo fato de legitimar em instâncias ilegítimas o infame ao ponto de transformá-lo apenas em citação, sem dar voz para esses homens. Giorgio Agamben (2007) chama-nos atenção para esse aspecto quando analisa o ensaio de Foucault sobre a infâmia, pois, para ele, "as vidas infames aparecem apenas por terem sido citadas pelo discurso do poder, fixando-as por um momento [...] algo naquela infâmia exige o próprio nome, testemunha de si para além de qualquer expressão e de qualquer memória" (AGAMBEN, 2007 , p. 58). Fica notória a necessidade de ouvir os infames, mas isso lhes é negado. Ouvi-los pode significar ter que realizar o desnudamento de tudo aquilo que compóe a "natureza" ordinária que apresentam. De certa maneira, é isso o que faz o jurado de Doze homens e uma sentença ao desvelar os meandros por trás das evidências que levaram o réu a uma pré-condenação por parte de todo o restante do júri. 
O que seria a infâmia? Quem é infame? Como se identifica o infame? Essas são algumas questóes problematizadas por Michel Foucault (1992) no ensaio $A$ vida dos homens infames, publicado em 1977, que tomo de pronto para problematizar aqui a insistência de construção da figura infame sem que ao menos se analise: sua real infamidade! Nesse ensaio, o filósofo compreende que o infame poderia configurar-se como:

Vidas que são como se não tivessem existido, vidas que não sobrevivem senão do choque com um poder que mais não quis que aniquilá-las, ou pelo menos apagá-las, vidas que a nós não tornam a não ser pelo efeito de múltiplos acasos (FOUCAULT, 1992, 102).

Essas vidas infames formam a característica fundamental do réu, sem nome, sem identidade do filme Doze homens e uma sentença, pois, como já referimos, há uma necessidade de transformar o réu em mais um dado estatístico, sendo tăo somente aniquiladas e apagadas enquanto vida, enquanto existência. $\mathrm{O}$ próprio fato de náo ter nome prenuncia sua condição infame, associado à debalde condição pobre, migrante, suburbano, que mal sabe falar o idioma.

Estes estereótipos denunciam a existência de mais uma forma de infame, o que Foucault (1992, p. 102-103) vai chamar de "aparentemente infames" ou um falso infame, que seria aquele marcado pelas "malfeitorias que se lhes atribuem, do respeitoso horror que inspiraram, são de facto homens da lenda gloriosa, mesmo que as razóes desse renome sejam inversas das que fazem, ou deveriam fazer, a grandeza humana”. Esse infame aproximase da ideia que a ele foi imputada, a fama de seus delitos e malfeitorias. Mas, pensando nas personagens analisadas neste estudo, será que há infâmia naqueles que, por pré-conceito, estavam resolutos a condenar o jovem sem ao menos avaliar os fatos com detalhes, ou, em outras palavras, será que, só pelo fato de ter uma realidade marcada pelo delito e pela pobreza, esses homem o condenam de antemão?

Foucault (2002) salienta também que existe outra forma de infâmia, a qual se aproxima bastante dessa posição infame da maioria dos membros daquele júri. Para o teórico, são eles "os pobres espíritos extraviados por caminhos desconhecidos, esses são infames a todo o rigor; já não existem senão por via das poucas palavras terríveis que estavam destinadas a torná-los indignos, para sempre, na memória dos homens". Essa forma de conceber outros homens infames está relacionada a práticas judiciárias, sendo que: 
As práticas judiciárias - a maneira pela qual, entre os homens, se arbitram danos e as responsabilidades, o modo pelo qual, na história ocidental, se concebeu e se definiu a maneira como os homens podiam ser julgados [...] me parece uma das formas pelas quais nossa sociedade definiu tipos de subjetividade, formas de saber e, por conseguinte, relaçōes entre homem e verdade (FOUCAULT, 2002, p. 11).

Entretanto, no ensaio sobre a infâmia, de Foucault, existe uma preocupação excessiva em considerar que a literatura "mais do que qualquer outra forma de linguagem, é a ela que continua a ser o discurso da - infâmia: cabe-lhe dizer o mais indizível - o pior, o mais secreto, o mais intolerável, o vergonhoso" (FOUCAULT, 1992, p. 127), pois seria inadmissível que além da ficção fosse possível aceitar tais práticas infames.

É o que ocorre nas narrativas tanto da literatura quanto do cinema aqui analisadas, um grande jogo discursivo que elabora e reelabora as verdades e ainda mostra como, nesse universo de leitura dos crimes, todos são infames, mesmo quando existem diferenças entre esses infames, já que o nível de comprometimento desses homens será medido por sua posição social e por sua importância como atores no interior das redes de poder de que fazem parte.

O filme de Sidney Lumet concebe a falência da justiça, que delega o poder condenatório aos que nada sabem, ou muito pouco, sobre os códigos jurídicos e são influenciados por suas idiossincrasias, consequentes de uma sociedade igualmente idiossincrásica. A tragédia clássica aponta, no caminho do nascimento do tribunal, um julgamento afetado por relaçóes de poder geradoras de medidas diferentes para criminosos diferentes. Por último, na tragédia de Shakespeare, o caminho não será a diferença social, mas a necessidade da confissão para legitimar a vingança. As três produçóes acabam por discutir de formas distintas várias maneiras de entendermos aspectos infames do tribunal.

\section{Referências}

AGAMBEN, Giorgio. O autor como gesto. In: __. Profanaçóes. Tradução e Apresentação Selvino José Assmann. São Paulo: Boitempo, 2007.

ARISTÓTELES. Diferentes espécies de poesia segundo os objetos imitados. In: . Arte Retórica e Arte poética. Rio de Janeiro: Ediouro, 2000. 
BENVENISTE, Emile. O Vocabulário das Instituiçóes Indo-européias: Poder, Direito, religiáo. V. 2. Tradução D. Bottmann. Campinas: UNICAMP, 1995.

DOSTOIÉVSKI, Fiódor. Crime e Castigo. Tradução Luiz Cláudio de Castro. Rio de Janeiro: Ediouro; São Paulo: Publifolha, 1998.

ÉSQUILO. Eumênides. In: Oréstia: Agamêmnon, Coéforas, Eumênides. Tradução do Grego, introdução e notas de Mário da Gama Kury. 8. ed. Rio de Janeiro: Zahar, 2010.

FOUCAULT, Michel. A verdade e as formas jurídicas. Tradução Roberto Cabral de Melo Machado e Eduardo Jardins Morais. Rio de Janeiro: NAU, 2002.

A vida dos homens infames. In: O que é um autor? Lisboa: Passagens. 1992. p. 103-104.

GOETHE, Johann Wolfgang. Fausto: Quadro V, Cena I. Tradução Antônio Feliciano de Castilho. Clássicos Jackson. v. 15. Aveiro-Portugal: Universidade de Aveiro; W. M. Jackson, 1956.

LUMET, Sidney. Doze homens e uma sentença. Roteiro: Reginald Rose. Drama. Estados Unidos, 96 min., 1957. Disponível em: <http:// www.youtube.com/watch?v=vHZhN4IccXs>. Acesso em: 01 out. 2015.

SHAKESPEARE, Willian. Hamlet. Tradução F. Carlos de Almeida Cunha Medeiros e Oscar Mendes. São Paulo: Virtualbooks; M\&M, 2000.

Augusto Sarmento-Pantoja - augustos@ufpa.br

Manuscrito recebido em 26 de maio de 2015 e aceito em 26 de junho de 2015. 